\title{
Die Reformasie en Skrifinterpretasie: Die nuwe wat die Reformasie gebring en ook moontlik gemaak het
}

\author{
J P (Kobus) Labuschagne \\ Departement Kerkgeskiedenis en Kerkreg \\ Universiteit van Pretoria
}

\begin{abstract}
The Reformation and the interpretation of the Scriptures

The aim of this article is to emphasize new trends in the interpretation of the Scriptures that were brought about by the Reformation and that were consequently made possible for the future. Reformation thinking and modern and contemporary thinking are compared and analyzed in order to establish the consequences of the openness created by the Reformation, in response to Medieval objectified thinking in which the Church always had a final and an arrived definition and statement. What should therefore be avoided is the misconception that Reformation thinking represented an arrived and stagnated way of doing theology.
\end{abstract}

\section{INLEIDING}

Soos dit gaan in die geheel van ons lewe, waarin ons nie ontkom aan die wêreld rondom ons wat met sy gebeure, vrae en invloede ons konfronteer tot respons en keuses wat gemaak moet word, so gaan dit noodwendig ook op die teologiese terrein. Die teologiebeoefening is immers deel van die geheel van ons lewe. Die stempel van die tyd waarin ons lewe is of allesoorweldigend of minstens maak ons, in een of ander rigting, ons keuses in relasie tot die sleutelbestanddele van die tydsgees. In die teologiese debat is dit ook nie anders nie. Die invloed van prominente persone skemer telkens deur in ons denke en die keuses wat ons maak.

Om wel buitengewone en ingrypende verandering in die gang van die ontwikkeling teweeg te bring, om wêrelde om te keer, vra meer as die gewone, vra die verskyning van reuse intellektuele figure, "Wundermänner" (wondermense), om 'n woord van Martin Luther oor te neem (Bornkamm 1965:199). Die Reformasie was so 'n ingrypende verandering, met konsekwensies tot vandag. 


\section{Die Reformasie en Skrifinterpretasie}

Die Reformasie het wêrelde omgekeer en 'n nuwe gang van sake gebring: Vir die Westerse kerk het dit uit een stroom twee nuwe hoofstrome gebring, van Protestants en Rooms. In die Westerse samelewing het dit nie alleen op verskillende wyses die invloed van die Christelike moraliteit afgedruk nie, maar in die omwentelinge wat gevolg het, het Roomse aggressie later tragies in godsdiensoorloë laat ontketen.

Meer spesifiek, was die Reformasie se nuwe benadering tot die Skrif eweneens ingrypend, en dit het daarom ingrypende verandering uitgespel in sy konsekwensies vir leer en lewe - met daarby implikasies vir die interpretasie van die Skrif tot vandag. Vir die interpretasie van die Skrif in ons eie tyd, bly dit daarom belangrik om op hoogte te wees van die nuwe wat die Reformasie gebring het en van die denke wat die Reformasie vir die toekoms oopgemaak het.

Die doel van hierdie artikel is om 'n bydrae te probeer maak, tot ' $n$ groter bewuswording van die nuwe wat die Reformasie gebring het en ook moontlik gemaak het. Uiteindelik bly daar hermeneuties vier dinge baie belangrik vir hierdie studie om aan te toon:

- Dat die Reformasie se Skrifinterpretasie in sy kern 'n oop benadering was, wat ' $n$ finale uitspraak in uitleg onmoontlik gemaak het.

- Dat die Reformasie se benadering van die Skrif 'n kritiese ingesteldheid ten opsigte van bron en teks weerspieël het.

- Dat die Reformasie se hermeneutiese benadering en kritiese ingesteldheid daartoe aanleiding gegee het dat die daaropvolgende Protestantse hermeneutiese benaderings en kritiese ondersoek dinamiese ontwikkelinge gaan toon het, veral vanaf die 19de eeu, en nog steeds toon.

- Dat die Reformasie se uitgangspunte in die hedendaagse hermeneutiese debat nog steeds waardevol en relevant bly, soos byvoorbeeld in die debat oor die verstaanshorisonne van van binne bepaaldheid en van buite bepaaldheid.

Ons moet wegkom van die verkeerde persepsie dat die Reformasie gestolde denke sou verteenwoordig. Ons het nodig om die Reformasie weer raak te sien in die werklikheid van sy dinamiese interaksie met sy eie periode, sy voorafgaande periodes, en ook sy daaropvolgende periodes. Wanneer ons bewus word van die Reformasie se dinamiese interaksie, ondervind ons ook 
dat sy stem ons dwing tot luister, en bring tot nadenke, en lei tot respons. In onbevangenheid sal ons, soos in die geval van baie ander stemme uit die verlede, nooit werklik klaar wees met die stem van die Reformasie nie, dit is wanneer ons die Reformasie nie in ons eie pakkie van vooropgestelde idees toevou en neutraliseer nie. Die Reformasie se stem sal aanhou gehoor word, en in aansluiting by die gedagtes van David Tracy wil ons dan inderdaad van die hermeneutiek se soeke na waarheid sê (in Thiselton 2007:112; my parafrase):

Waarheid in die hermeneutiek mag altyddeur onvolledig wees of ontoereikend, maar relatief voldoende in 'n spesifieke tyd en situasie, en tog voortdurend oop vir die toets van koherensie (waar alles begin inpas en saakmaak) en die toets van eksistensiële betekenisvolheid, om uiteindelik wel onafwendbaar te wys in die rigting van die self-openbaring van God in Jesus Christus - in God se liefde en God se genade.

\section{INGRYPENDE VERANDERING DEUR DIE REFORMASIE SE INTERPRETASIE VAN DIE SKRIF WAT NUWE DEURE OOPMAAK VIR DIE TOEKOMS}

Die Reformasie het die teologie se fokus op die Heilige Skrif geplaas soos nooit tevore. Daarmee was die Middeleeue se kerklike-sê en gesag onmiddellik in die gedrang. Wanneer die Reformasie die gesag van die Skrif alleen (sola Scriptura) vestig as die basis vir leer en lewe, waarna telkens en voortdurend teruggekeer kan en moet word, is die ingrypende betekenis daarvan:

- $\quad$ dat die Reformasie die gearriveerde denke wat in die Middeleeuse kerk ontwikkel het, verwerp het

- $\quad$ en die teologiese denke vir hede en toekoms oopgemaak het, die kerklike leerstellings vir altyd oopgemaak het,

- $\quad$ sodat daar altyd en weer besin kon word oor leer en lewe primêr vanuit die Skrif.

Die implikasies hiervan vir die toekoms was dat daar telkens opnuut vanuit die Skrif na nuwe antwoorde op nuwe vrae en ou vrae gesoek sou word. Nuwe insigte sou telkens daartoe aanleiding gee (soos by die Reformasie) dat vanuit nuwe invalshoeke die Skrif ondersoek word. Die Reformasie het 


\title{
Die Reformasie en Skrifinterpretasie
}

eenvoudig nie meer ruimte gelaat vir menslike gearriveerde denke nie.

Hervorming was immers in Reformasie-denke 'n proses wat aangaan en nooit weer ophou nie, voortgaande reformasie - ecclesia reformata, ecclesia semper reformanda ('n hervormde kerk, [is] 'n kerk wat altyd nodig het om te hervorm).

Sonder dat hy die werklike diepte van die betekenis van sola Scripture nog kon begin verstaan het, het Johann Eck (die hoofsekretaris van die aartsbiskop van Trier, wat namens die Keiser die woord moes voer by die Ryksdag van Worms [April 1521], in die ondervraging van Martin Luther, en nie dr Johann Eck wat Luther in die Leipzig-debat [Julie 1519] teengestaan het nie), tog reeds iets van die waarheid raakgevat. En dit bly merkwaardig! In sy beroemde toespraak by Worms, wat hy afgesluit het met die bekende woorde - "Hier staan ek, ek kan nie anders nie, mag God my help, Amen" het Luther volgehou: “... ek is gebind deur die Skrif wat ek aangehaal het en my gewete is gebonde aan die Woord van God" (Luther 1970:112). Dan volg nou die merkwaardige: Hierop het Johann Eck wél begryp dat alles nou in beweging was, dat die kerklike uitsprake en leerstellings nie meer finaal kon wees nie, wanneer mense hulle telkens op die Skrif kon beroep. Eck het gesê:

\begin{abstract}
... and you wish to be refuted by means of Scripture. In this you are completely mad. For what purpose does it serve to raise a new dispute about matters condemned through so many centuries by church and council? Unless perhaps a reason must be given to just anyone about anything whatsoever. But if it were granted that whoever contradicts the councils and the common understanding of the church must be overcome by Scripture passages, we will have nothing in Christianity that is certain or decided.
\end{abstract}

(Luther 1970:113)

Anders as die vroeë kerk, het die Middeleeuse kerk die leer van die "depositum fider" ontwikkel, waarvolgens 'n sekere skat van geloofswaarhede aan die kerk toevertrou is, waarvan geeneen verlore mag gaan nie. Die gedagte wat daarmee ontwikkel, is dat die kerk se woord finaal is en dat daar gebly moet word by die kerklike uitsprake. Die direkte gevolg van hierdie Middeleeuse beskouing vind sy neerslag in die Roomse leer van die onfeilbaarheid van die kerklike dogmas by die Konsilie van Trente (15451563) en die Eerste Vatikaanse Konsilie (1869-1870) (vgl Lohse 1985:7, 8). Teenoor die Middeleeuse en Roomse beskouing van, "ons behoort alleen te staan by die beslissing van die Kerk", sê Johannes Calvyn in sy Kommentaar op I \& II Petrus dat die Skrif toegelaat moet word om "sy eie gesag" te handhaaf, en sê hy, "weet dat niks is meer vas en seker as die onderrig van 
die Skrif” (Calvin 1963:225). Van Luther sê Robert D Linder: “... Luther se leerstellige posisie het meer volledig ontwikkel om die gesag van die Bybel in te sluit in die plek van die kerklike leerstellings soos dit bemiddel is deur die pous ..." (Linder 1974:830). Waar Luther nou die Middeleeuse kerklike leerstellings onderwerp aan die interpretasie en gesag van die Skrif, handhaaf hy daarmee, bo-alles, die gesag van Christus, en sê dan: "Ek verhef myself nie bo die doktore en konsilies nie; ek verhef Christus bo alle leermeesters en konsilies" (Lohse 1985:14). Wanneer die Reformasie wél die vroeë kerk se konfessies aanvaar, is dit omdat hulle dit ooreenkomstig die Skrif geïnterpreteer het; die Reformasie het immers uitdruklik gestel dat die kerklike leerstellings onderworpe was aan die normerende gesag van die Skrif (vgl Lohse 1985:14). Met die gesag wat die Reformasie aan die Skrif toeken, bring die Reformasie dus vir sy komende geslagte, vir sy voortspruitende tradisies (denominasies), 'n skerp wegswaai van die Roomse gearriveerde beskouing van die kerklike leer.

Die Roomse beskouing van die kerklike leer, wat sy objektiewe inhoud betref, was en is nog steeds dat dit 'n waarheid geopenbaar deur God en gedefinieer deur die kerk is (by wyse van 'n uitspraak van 'n konsilie, 'n ex cathedra beslissing van die pous, of as iets wat algemeen in die kerk geleer word). Deel van hierdie siening is die onbuigsame Roomse beslissing dat, wat objektiewe inhoud betref, die gedefinieerde dogma van die kerk sonder fout is, dat dit nie weerspreek mag word nie, maar dat daar alleen bygevoeg en uitgebrei kan word vanuit nuwe vrae en nuwe situasies (vgl Lohse 1985:4, 5, 13). Vir die Reformasie se Skrifbeskouing bly die gesag van die kerklike leerstellige uitsprake (wat hulle saam met die vroeë kerk waardeer as belydenis of konfessies) relatief tot die normerende gesag van die Skrif, en relatief bo-alles tot die gesag van Christus (Lohse 1985:14). Later sou in Protestantse geledere, met hierdie deur wat die Reformasie oopgemaak het, Karl Barth se beskouing wye aanvaarding vind, die beskouing naamlik dat die kerklike en tegelyk menslike leerstellings of dogmas slegs tekens is van die ware dogma, en slegs vorms is waarin die ware dogma tot uitdrukking kom. En daarmee word gesê dat die kerklike leerstellings nie meer as 'n poging kan wees om iets tot uitdrukking te bring van die waarheid van God se openbaring in Jesus Christus, waarvan die Bybel die optekening en getuienis is (Lohse 1985:11).

'n Diskontinuïteit ten opsigte van die gearriveerde en finale soort van kerklike denke van die Middeleeue is verder uitdruklik beklemtoon deur die Reformasie se keuse vir die oorspronklike Hebreeuse en Griekse teks van die Bybel in plek van die Latynse Vulgaat, om met die oorspronklike tale nader aan die waarheid van die Skrif te kom. R A Muller (1998:128; my parafrase) 


\section{Die Reformasie en Skrifinterpretasie}

sê: "Die Protestantse aandrang op die gesag van die oorspronklike tale van die teks staan op die veronderstelling dat die woorde van die teks in hierdie tale alleen finale en beslissende outoriteit gehad het."

Die Renaissance se benadering van terug na die bronne (ad fontes), wat deur die Reformasie gevolg is, sou beslis met sola Scriptura tot ander insigte lei. Wat dan voorheen in die kerk gesê is op basis van die Latynse vertaling van die Vulgaat het eenvoudig vir die Reformasie nie dieselfde gesag gedra nie. Die verskil tussen die Griekse teks en die Latynse teks kon inderdaad soms lei tot groot verskille in leerstellige interpretasie, soos byvoorbeeld by Lukas 1:28. In die Griekse teks verwys die engel na Maria met

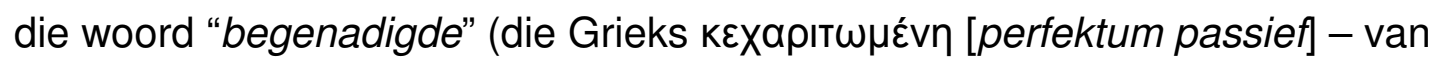
die werkwoord xapıтó( $)$, om te sê dat Maria die ontvanger was van God se genade en guns. Maar in die Latynse teks word heeltemal iets anders gesê, wanneer die engel na Maria verwys met die woorde "vol genade" (die Latyn gratia plena). Laasgenoemde kan so interpreteer word dat Maria genade in haarself gehad het, wat dus van haar' $n$ heel buitengewone persoon gemaak het.

Die Reformasie se terugkeer na die oorspronklike Hebreeuse en Griekse teks van die Bybel was alreeds 'n duidelike teken van die Reformasie se kritiese ingesteldheid, in die bestudering van die Skrif. Daarmee sê die Reformasie dat nie alles aanvaar sal word wat op die veronderstelling van 'n Skrifgebaseerdheid gesê word nie, want die onmiddellike vraag is: Watter teks is gebruik?

Die kritiese-ingesteldheid van die Reformasie sou ook verder as die bronteks gaan, en byvoorbeeld die inhoud van die teks en die outeur van die teks bevraagteken. Luther is daarom krities ingestel ten opsigte van die inhoud van Jakobus en Openbaring. Bainton verduidelik:

Luther read the New Testament in the light of the Pauline message that the just shall live by faith and not by works of the law. That this doctrine is not enunciated with equal emphasis throughout the New Testament and appears to be denied in the book of James did not escape Luther, and in his preface to the New Testament of 1522 James was stigmatised as "an epistle of straw". Once Luther remarked that he would give his doctor's beret to anyone who could reconcile James and Paul. Yet he did not venture to reject James from the canon of Scripture, and on occasion earned his own beret by effecting a reconciliation. "Faith," he wrote, "is a living, restless thing. It cannot be inoperative. We are not saved by works; but if there be no works, there must be something amiss with faith."

(Bainton 1950:259) 
Bekend is ook Luther se bedenkinge oor die Openbaring-boek, omdat dit so moeilik verstaanbaar was. Hiervan sê Luther dan: " $n$ Openbaring behoort tog openbarend te wees" (Bainton 1950:261). In 'n beredenering oor wie die skrywer van Hebreërs was, skrywe Calvyn in Mei 1549 in 'n voorwoord tot sy Kommentaar op Hebreërs:

As to its author, we need not be greatly worried. Some think that the author was Paul, others Luke, others Barnabas, and others Clement, as Jerome says; yet Eusebius, in the sixth book of his Church History, mentions only Luke and Clement. I well know that in the time of Chrysostom it was received everywhere by the Greeks as among the Pauline epistles; but the Latins thought otherwise, especially those who were nearest to the apostolic times.

I can adduce no reason to show that Paul was its author ... The manner of teaching and the style sufficiently show that Paul was not the author, and the writer himself confesses in the second chapter that he was one of the disciples of the apostles ...

(Calvin 1963:1)

Ook wat ' $n$ kritiese ingesteldheid ten opsigte van die bestudering van die Skrif betref, het die Reformasie met tallose voorbeelde in kommentare en geskrifte duidelik die deure oopgemaak vir toekomstige kritiese ondersoek van die Skrif. Die Bybel as 'n boek wat deur mense geskrywe is, kom sterk na vore in hierdie kritiese benadering en ondersoek van die reformatore na vore. Dit neem egter nie weg nie dat die Bybel tegelyk vir die reformatore in bepaalde geïnspireerde sin God se Woord bly.

Verandering, as implikasie, was duidelik reeds ingeskrywe in die Reformasie se kritiese lees van die Bybel, en dit het 'n heel ander inhoud gegee aan die Bybelverstaan, leer en lewe van die gelowige as wat die Middeleeuse kerk gedoen het. Tog, wat nie voorsien kon word in die Reformasie-denke nie, was dat verandering later so sentraal en omvangryk en so tot die uiterste gedrywe sou word, soos in die postmoderne invloed in die Protestantse teologie sedert die laaste gedeelte van die 20ste eeu. In sy hermeneutiese beïnvloeding van die teologie, leer die postmoderne siening dat daar geen absolute of objektiewe waarheid in beide pluralisme en openheid is nie. Alles is onseker en nooit finaal. Ook taal het in groeiende moontlikhede uiteindelik nie 'n finale betekenis nie, en reflekteer 'n verstaan vanuit voortdurende verskuiwende konvensies. Jacques Derrida (geb 1930) sê taal vermy altyd ' $n$ finale betekenis. Alle strukturele denke van die verlede word vervang met die onbepaalbare en onafgehandelde openheid vir nuwe moontlikhede. Die postmoderne gebruik van metaforiese taal is in baie gevalle 


\section{Die Reformasie en Skrifinterpretasie}

uiteindelik alleen die interpreteerder se eie skepping, die interpreteerder se eie mite, op basis van die interpreteerder se eie vooronderstellings. Dit beteken dat ons in die postmoderne denke nie na meer kan strewe nie as om subjektief deel te probeer wees van dit wat gemoeid is met die waarheid (vgl Labuschagne 2007:45-48).

Soms mag ons so vasgevang wees in die eietydse teologiese debat, of die kritiese hermeneutiek wat eers sedert die 19de eeu ontwikkel het, dat ons nie raaksien watter belangrike deure vir verstaan reeds deur die Reformasie oopgemaak is nie, en wat dan in latere hermeneutiese ontwikkelings tot uitdrukking kom. So is daar in die hoofstrominge van die Reformasie, byvoorbeeld in die kommentare van Calvyn, 'n aanduibare hermeneutiese vasstelling van 'n nie-identiteit tussen Woord van God en woord van die mens in die Bybel, en vandaar word die hermeneutiese koers gedui op relasie tussen Woord van God en woord van die mens in die Skrif. Die relasie voltrek hom uiteindelik in die geloofsontmoeting van die mens met God in Jesus Christus, wanneer die sondaarmens deur die Gees van God die Woord van God, buite sy eie menslike toedoen, hoor en ontvang.

Die locus classicus vir Calvyn se siening van die Goddelike inspirasie van die Skrif vind ons in sy uiteensetting van die betekenis van 2 Tim. 3:16. Wanneer hierdie verduideliking van Calvyn gelees word los van sy hantering van die menslike aspekte van die Skrif, sou Calvyn verkeerdelik as fundamentalisties beskrywe kon word, veral wanneer hy byvoorbeeld van die Skrif praat as "gedikteer deur die Heilige Gees" (vgl Puckett 1998:174). Calvyn het egter die Skrif hanteer in die lig van die Skrif se Goddelike én menslike kant. Die menslike kant van die Skrif word byvoorbeeld duidelik wanneer hy in sy Kommentaar op Romeine in die "Epistle Dedicatory" die plig van 'n getroue interpreteerder spesiaal uitlig. Hy stel die getroue interpreteerder daarop in om die gedagtes van die skrywer van 'n Bybelboek oop te maak, dis sy hooftaak, en wérklik dan waarsku hy al teen wat in ons tyd 'n belangrike aspek van die debat is. Waarteen Calvyn al waarsku, is wat Gadamer in ons tyd noem die refleksiewe projeksie van die ondersoeker se oortuigings om bepalend in te werk op die boodskap van die teks (waarop ons later sal ingaan). Oor "the best mode of expounding Scripture" sê Calvyn dan:

... the chief excellency of an expounder consists in lucid brevity. And, indeed, since it is almost his only work to lay open the mind of the writer whom he undertakes to explain, the degree in which he leads away his readers from it, in that degree he goes astray from his purpose, and in a manner wanders from his own boundaries.

(Calvin 1947:xxiii) 
Dis inderdaad belangrik dat Calvyn ook praat van die nodigheid van nederigheid in die interpretasie van die Skrif (Calvin 1947:xxvii). Dikwels het Calvyn interpretasies van ander verwerp wanneer hy oortuig was dat dit teen die bedoeling van die outeur was, en dan by Psalm 87 verwys hy na beide die Goddelike én die menslike in die Bybel: "Ons moet die bedoeling van die profeet oorweeg, of eerder dan die doel van die Gees van God, wat deur die mond van die profeet praat" (Puckett 1998:174). Reeds al in die "Outeursvoorwoord" van sy Kommentaar op die Psalmboek skrywe Calvyn in die onderskeiding van die menslike en die Goddelike van die Skrif:

I have been accustomed to call this book, I think not inappropriately, "An Anatomy of all the Parts of the Soul;" for there is not an emotion of which any one can be conscious that is not here represented as a mirror. Or rather, the Holy Spirit has here drawn to the life all the griefs, sorrows, fears, doubts, hopes, cares, perplexities, in short, all the distracting emotions with which the minds of men are wont to be agitated.

(Calvin 1949:xxxvi, xxxvii)

Afgesien van die menslike kant van die Skrif, openbaar Calvyn groot ontsag en verering vir die Bybel as God se Woord: "Such veneration we ought indeed to entertain for the Word of God" - en in die uitleg daarvan beklemtoon hy dat dit gedoen sal word "with great discretion and with great sobriety" (Calvin 1947:xxvii). En voeg dan by (en weer kan vergelyk word met die kontemporêre debat oor refleksie, soos by Gadamer):

And if it be deemed a great wickedness to contaminate any thing that is dedicated to God, he surely cannot be endured, who, with impure, or even with unprepared hands, will handle that very thing, which of all things is the most sacred on earth. It is therefore an audacity, closely allied to a sacrilege, rashly to turn Scripture in any way we please, and to indulge our fancies as in sport; which has been done by many former times.

(Calvin 1947:xxvii)

Dis duidelik dat, vir Calvyn, dit God sélf is wat die relasie tussen God se Woord en mensewoord in die Bybel daarstel, wanneer Calvyn byvoorbeeld sê: "The other parts of Scripture contain the commandments which God enjoined his servants to announce to us" (Calvin 1949:xxxvii). In sy Institusie (Boek I, hoofstuk vii, 4\&5) sê Calvyn dat dit die Heilige Gees is wat God se Woord in ons harte bring: 


\section{Die Reformasie en Skrifinterpretasie}

But I answer, that the testimony of the Spirit is superior to reason. For as God alone can properly bear witness to his own words, so these words will not obtain full credit in the hearts of men, until they are sealed by the inward testimony of the Spirit. The same Spirit, therefore, who spoke by the mouth of the prophets, must penetrate our hearts, in order to convince us that they faithfully delivered the message with which they were divinely intrusted ...

Scripture, carrying its own evidence along with it, ... owes the full conviction with which we ought to receive it to the testimony of the Spirit.

(Calvin 1964:72)

Die relasie tussen Woord van God en mensewoord in die Bybel word by Martin Luther voltrek deur God sélf. Hy sien dit dus nie anders as Calvyn nie. En daarom sal Luther byvoorbeeld in sy lesings by die uitleg van Romeine 1:2 skrywe: "But through the prophets the promise is given in time and in human speech. This is a wonderful proof of the grace of God, that above and beyond the eternal promises He gives the promise also in human words, not only in spoken words but also in written ones" (Luther 1972:145).

Luther beklemtoon dat God sy Woord nie alleen deur profete aan ons gee nie, maar ook deur die Heilige Skrif (Luther 1972:146). En dis ook God sélf wat ons lei om die Skrif te verstaan; in sy laaste preek op 15 Februarie 1546, in Eisleben, wat gehandel het oor Matteus 11:25-30, sê Luther: "This is a fine Gospel and it has a lot in it. Let us talk about part of it now, covering as much as we can and as God gives us grace" (Luther 1973:383). En in sy Lesings oor die Psalms sê Luther ook dat God ons lei om te verstaan: "I confess frankly that even to the present day I do not understand many psalms and, unless the Lord enlightens me through your help, as I trust He will, I shall not be able to interpret them" (Luther 1974:8).

Die verstaan van 'n duidelike onderskeiding tussen Woord van God en woord van die mens in die Bybel is ook nie in wese anders by Martin Luther as by Johannes Calvyn nie. Reeds by die Ryksdag van Worms (hierbo vermeld) was die aanduiding Skrif (soos deur die mens geskrywe) en sy onderskeidende realiteit as Woord van God opmerklik in Luther se sin: "... ek is gebind deur die Skrif wat ek aangehaal het en my gewete is gebonde aan die Woord van God" (Luther 1970:112).

Luther se baie realistiese siening van die mens, in sy menslike gebreke, raak uiteindelik noodwendig sy hermeneutiek, wanneer onthou moet word dat dit mense is wat die Bybel geskrywe het. By die Heidelberg Disputasie (Mei 1518) het Luther, onder meer, in 'n baie skerp ontleding van die mens gesê, en dit sluit alle mense in, ook die gelowiges en die vrome 
teoloë - en selfs dan die wonderlike mense wat die Bybelboeke geskrywe het, is nie uitgesluit nie: "... we by nature love our will more than the will of God. ... We are all like that. Where now is the love of God above all things? See, we do not love God more than our life and our will" (Luther 1971:69). En dan, bykomend gesien, het hy daar by Heidelberg, ook dit gesê van die mens:

The works of God (we speak of those which he does through man) are thus not merits, as though they were sinless ... This is a comparison. If someone cuts with a rusty and rough hatchet, even though the worker is a good craftsman, the hatchet leaves bad, jagged, and ugly gashes. So it is when God Works through us.

(Luther 1971:45)

God werk ook deur die mense wat die Bybel skrywe, maar dan gaan dit in sy hermeneutiek juis beteken dat daardie skryfwerk ook die beperkinge van die mens sal dra. Luther bly konsekwent in hierdie siening. Hierdie skerp kritiek op alle mense weerhou hom gevolglik nie daarvan om die skrywer van 'n Bybelboek, soos Jakobus, dan selfs ernstig te kritiseer nie. In sy Lesings oor die Psalms is hy, hermeneuties gesien, dus bewus dat hy 'n mense-skrywer moet interpreteer. Maar let wel, soos by Calvyn, wil hy dit nogtans doen sonder om die skrywer in die ondersoeker se eie subjektiewe verpakking in te dwing: "Therefore, since I am undertaking to interpret a prophet ... I wished, as I have said to omit this little word of commendation and let the prophet himself show himself to you ... " (Luther 1974:9).

Dat hy met 'n menslike outeur werk, is duidelik in Luther se Voorwoord van sy Kommentaar op Romeine, waar hy dan van die boek sê: "To begin with we must have knowledge of its language and know what St Paul means by the words, law, sin, grace, faith, righteous, flesh, spirit, etc, otherwise no reading of it has any value ..." (Rupp \& Drewery 1970:95).

Daarmee ontken Luther nie die hand van God in die Bybel nie, maar maak wel 'n duidelike onderskeiding tussen woord van die mens en Woord van God. Van die Woord van God in die Bybel sê hy in sy kommentaar op 1 Korintiërs 15: "... having the precious Word in its purity, be concerned and intent on being guided by it, apprehend it well and firmly, adhere to it ..." (Luther 1973(a):61). Roland H Bainton sê van die aanduidings van Luther se onderskeiding tussen Woord van God en woord van die mens in die Bybel, wat eintlik reeds duidelik is wanneer Luther die gesag van Christus bo-alles handhaaf: 


\section{Die Reformasie en Skrifinterpretasie}

The Bible for him was not strictly identical with the Word of God. God's Word is the work of redemption in Christ which became concrete in Scripture as God in Christ became incarnate in the flesh; and as Christ by the incarnation was not denuded of human characteristics, so the Scripture as the medium of the Word was not divested of human limitations.

(Bainton 1950:258, 259)

Hierdie belangrike onderskeiding, van 'n nie-identiteit tussen Woord van God en woord van die mens in die Bybel, kwalifiseer vervolgens wat gesê word ten opsigte van Skrifinspirasie deur die Heilige Gees, en staan nie teenoor dit nie.

Wat nou volg uit die erfenis van die Reformasie is drie hoofstrome onder die Protestantse nageslag:

- Die eerste stroming (veral in Piëtisme, Metodisme en Réveil), fokus in hulle Skrifinterpretasie alleen op die inspirasiebeskouing van die Reformasie, om daarmee prakties die Reformasie se verstaan van die Skrif in te perk, en lei dan in die post-Reformasie tot 'n fundamentalistiese benadering waarin 'n identiteit vasgestel word tussen Woord van God en woord van die mens in die Bybel, en dit kom dan tot uitdrukking in beskouings soos die onfeilbaarheid van die Skrif en die verbale inspirasie van die Skrif.

- Die tweede stroming, veral vanaf die $19 \mathrm{de}$ eeu, voer die Reformasie se nie-identiteit tussen die Woord van God en woord van die mens in die Bybel veel verder, om in aansluiting by die heersende filosofiese metodologie tot ingrypende nuwe benaderings tot die Skrif te kom, en voorbeeld hiervan word gevind in die historiese kritiek van die 19de eeu en die daaraan verwante liberale teologie (bv F D E Schleiermacher).

- Die derde stroming wat volg, voer ook die Reformasie se nie-identiteit tussen Woord van God en woord van die mens in die Bybel verder, in volgehoue teologiese debat met die tweede stroming veral, en tegelyk ook in debat met die eietydse filosofie en ander relevante wetenskaplike dissiplines, maar behou nogtans baie sterk as hermeneutiese vertrekpunt die self-openbaring van God in Jesus Christus in die geskiedenis. Wat laasgenoemde stroming betref, kan veral verwys word na die dialektiese teologie van Karl Barth en die invloedsfeer wat op hom volg. 
Die drie strominge val verder uiteen in 'n groot aantal aanduibare teologieë wat uiteindelik almal deel uitmaak van die erfenis van die Reformasie, teologieë wat oor denominasionele grense gaan, oor die grense van byvoorbeeld Lutheranisme, Calvinisme, Anglikanisme en Metodisme.

\section{VERSKILLENDE VERSTAANSHORISONNE - INTERPRETASIE MET 'N VAN BINNE BEPAALDHEID EN INTERPRETASIE MET 'N VAN BUITE BEPAALDHEID}

Deur Reformasie-denke saam met moderne en kontemporêre denke te analiseer en te vergelyk, word dit duidelik waarheen die oop denke van die Reformasie gelei het, in respons tot die gearriveerde en gestolde denke van die Middeleeue, waarin die Middeleeuse kerk telkens in finale sin die laaste sê gehad het in definisies en uitsprake.

Die Reformasie se openheid het uiteraard gaandeweg verskille in benadering en interpretasie van die Skrif moontlik gemaak. Openheid is immers nie openheid as verskille dan nie ook moontlik kan wees nie. Wanneer vervolgens verwys word na verskillende verstaanshorisonne, word die begrip verstaanshorison gebruik in aansluiting by Anthony $C$ Thiselton se begrip "horizons of understanding" (Thiselton 2007:177v).

Soos tot dusver aangetoon, het die Reformasie se verstaan en hantering van die Skrif 'n openheid in verstaanshorison geopenbaar, waaruit, onder sy nageslagte, weer verskillende ander verstaanshorisonne ruimte vir bestaan en ontwikkeling kon vind. Dis so anders as die Middeleeuse kerk, en die latere Roomse kerk wat gevolg het, waar die openheid ontbreek en waar die kerklike leerstellings dan die finale woord en verstaan word. In die ryke hermeneutiese verskeidenheid wat onder die Reformasie se nageslagte volg, kan lyne van min of meer kontinuïteit aangetoon word, maar dan is daar ook tekens van radikale verskil in hermeneutiese benadering. Veral sedert die 19de eeu volg daar, binne bepaalde strominge, soos byvoorbeeld die historiese kritiek en die liberale teologie, radikale verskille met die verlede.

Hermeneutiek as begrip en as wetenskaplike dissipline ontwikkel eers werklik vanaf die 19de eeu. Dit beteken dat die Reformasie nie dieselfde sterk hermeneutiese bewussyn as ons in ons tyd het nie. Dit meen egter nie dat die Reformasie nie 'n hermeneutiek gehad het nie, omdat hulle nie die woord hermeneutiek gebruik het nie. Allesbehalwe! Dit was juis die Reformasie se interpretasie en hantering van die Skrif wat 'n breuk met die verlede gebring het, verantwoordelik was vir groot veranderinge, en wat deure oopgemaak vir die hermeneutiese ontwikkeling wat gevolg het. 


\section{Die Reformasie en Skrifinterpretasie}

Wanneer nou gefokus word op radikale en groot verskille tussen die Reformasie se verstaanshorison en die verstaanshorisonne van die 19de eeu en verder, kan bepaalde tendense uitgewys word.

In die Reformasie se verstaanshorison word die Bybel interpreteer vanuit riglyne binne die Bybel self. Antwoorde op vrae word alles binne die verstaanshorisonne van die Bybel self gesoek. Primêr word die Bybel self gebruik om die Bybel mee te interpreteer. Dit dui op 'n hermeneutiek van binne - 'n van binne bepaaldheid (vgl Thiselton 2007:293). Hierteenoor vind ons in die 19de eeu 'n hermeneutiek wat baie sterk van buite bepaal word, wanneer die verstaanshorison bepaal word vanuit die kontemporêre filosofie en dan het ons 'n van buite bepaaldheid (vgl Thiselton 2007:293).

Binne die Reformasie se verstaanshorison van 'n van binne bepaaldheid het ons 'n hermeneutiek wat klem lê op 'n filologies-historiese interpretasie van die Skrif. Hierin is die Reformasie sterk beïnvloed deur die Renaissance. Filologies dui dan op die beste moontlike taalkennis van die brontale van die Bybel (Hebreeus en Grieks) wat die Renaissance en Humanisme van die 16de eeu kon aanbied, in hulle sterk strewe van terug na die bronne (ad fontes). Histories dui op 'n noukeurige ondersoek en ontleding van die historiese insig wat die Bybel self, van binne dus, aangebied het. Die Renaissance se studie van die Bybel, en ander antieke literatuur, het deur die volgehoue arbeid van die Renaissance-geleerdes groot verandering ondergaan, met die groot ontwikkeling van taalkundige insig en ook met die veel groter historiese bewustheid wat nou aan die orde kom. Christen eksegete van die 16de eeu het nou veel meer as in die verlede belangstelling getoon in die "historiese betekenis van die Bybel" (Puckett 1998:172). Oorspronklike historiese en kulturele konteks in die Bybel word nou deur die teoloë ondersoek en in ag geneem by die interpretasie van die boodskap, en daarby word literatuur se strukture, woordgebruik en idiome ook in berekening gebring.

Calvyn beklemtoon dat die mens geen vermoë in homself het om God te ken nie (Institusie boek I, hoofstuk v, 12-15): “... we are deficient in natural powers which might enable us to rise to a pure and clear knowledge of God ..." (Calvin 1964:62). En: "... the human mind, which thus errs in inquiring after God, is dull and blind in heavenly mysteries" (Calvin 1964:60). Hy beklemtoon: "... it remains that God himself must bear witness to himself from heaven" (Calvin 1964:62). In hoofstuk vi van sy Institusie sê hy: "God gives ... a better help to the knowledge of himself - viz. the Holy Scriptures" (Calvin 1964:4). En in hoofstuk ix van die Institusie praat hy van God se volle openbaring in Jesus Christus (Calvin 1964:363), en sê van die Seun van God: "He is more fully revealed to us under the Gospel" (Calvin 1964:363). Calvyn 
verduidelik dit so: Die genade van God, gemanifesteer in die God-mens Jesus Christus, is bekend gemaak deur die Evangelie (die Heilige Skrif) (vgl Calvin 1964:63-367).

In die voorwoord van sy Kommentaar op die Romeinebrief sê Calvyn van die "interpreteerder" dat hy die taak het "om die denke van die skrywer te ontvou" en dan waarsku Calvyn die interpreteerder teen wat genoem word "die mate waarin hy sy lesers weglei van die bedoeling van sy outeur" (Puckett 1998:173). Die verstaan van die Bybel moet uit die Bybel self vasgestel word. Dit herinner aan Augustinus (354-430) wat in sy De Doctrina Christiana (van 397) sy siening vir die interpretasie van die Skrif weergee en dan kan dit uiteindelik so saamgevat word, deur te sê dat Augustinus objektiewe prosedures volg waardeur hy die Skrif wou toelaat om te sê wat die Skrif selfstandig wou sê en die oorspronklike skrywer se bedoeling wou laat uitkom (vgl Klein et al 1993:36, 37). Ook Augustinus gaan dus uit van 'n van binne bepaaldheid.

Philip Schaff beskou Calvyn as die "grondlegger van moderne histories-grammatikale eksegese" (Puckett 1998:178). Puckett wys daarop dat die spanning in Calvyn se hermeneutiek tussen die deur die Heilige Gees geïnspireerde kant van die Skrif (die tradisionele Christelike benadering) en die verbinding daarvan met sy meer moderne benadering wat erkenning verleen aan die menslike element en diversiteit in die Skrif, verantwoordelik is vir hernude belangstelling hedendaags in veral Calvyn se kommentare (Puckett 1998:178, 179).

Luther se verstaanshorison bevestig 'n van binne bepaaldheid van die Skrif, wanneer hy leer dat die Skrif sy eie interpreteerder is (scriptura sacra sui ipsius interpres [Hagen 1998:218]). K Hagen wys daarop dat dit vir Luther beteken: "geen buite-gesag word benodig om geloofwaardigheid aan die Skrif te verleen nie" (Hagen 1998:219).

Vir Luther het die Skrif in sy kern alleen 'n Christologiese betekenis. Luther sê daarom byvoorbeeld in sy Lesings oor die Psalms: "Every prophesy and every prophet must be understood as referring to Christ the Lord, except where it is clear from plain words that someone else is spoken of. For thus $\mathrm{He}$ Himself says: 'search the Scriptures ... and it is they that bear witness to Me'" (John 5:39) (Luther 1974:7). Hagen sê dan tereg van Luther se hermeneutiek: "The core of Scripture is what drives, teaches and pronounces Christ (was Christum treibet). Treiben has to do with transportation; so that in Scripture, the important thing is to see that the sacred page drives us and brings us to Christ." "... Scripture alone means Christ alone" (Hagen 1998:218).

Vir Luther was daar inderdaad baie skerp en duidelik 'n realiteit groter as die Skrif, agter en bokant die Skrif, waartoe die Skrif ons moet help, en 


\section{Die Reformasie en Skrifinterpretasie}

daardie realiteit is Christus. Daar was 'n duidelike onderskeid tussen Christus en die Bybel; dit was bo-alles Christus. Maar Luther het 'n pad geloop voordat hy hierdie duidelike insig gehad het. En daardie pad het begin met 'n groot vraag: "Wie kriege ich einen gnädigen Gott?" - Hoe vind ek 'n genadige God? (Lohse 1985:160.) Hierdie vraag met sy antwoord bepaal vir Luther die hart van sy hermeneutiese benadering.

In sy worsteling het jonge Luther dit as 'n onredelike God beskou wat van die mens vra om te doen waartoe die mens nie in staat kan wees nie. God was vir hom 'n harde Regter. By die Universiteit van Erfurt het Luther die teologie van die Franciskaan en Nominalistiese filosoof, Willem Occam (c 1300-1349), geleer, en daarvolgens sal God nie sy genade weerhou van die mens wat doen wat hy kan doen nie. Ook dit het Luther nie teologies of prakties tevredegestel nie.

Teen 1514 begin Luther lig sien. In sy bestudering van die Bybel, veral Romeine 1:17, Psalm 71:2, en Romeine 4:5, ontdek Luther dat daar nie ' $n$ pad van die mens na God was nie, maar alleen 'n pad vanaf God na die mens toe - in Jesus Christus (vgl Lohse 1985:161). In Jesus Christus bewys God sy genade. In Christus is God nie 'n harde Regter nie, maar 'n Vader. Regverdiging voor God is 'n gawe wat die mens van God deur Jesus Christus in geloof ontvang. Die mens kan niks vermag tot sy eie verlossing en saligheid; hy ontvang dit as 'n gawe van God, deur geloof - in dankbaarheid. Dit beteken dat die mens in liefde God vertrou, soos 'n kind sy vader vertrou. Hierdie geloofsvertroue word die mens alleen deelagtig wanneer God Hom genadiglik tot die mens wend in Christus - wanneer Christus, in kruis en opstanding, verlossing en 'n nuwe lewe moontlik maak (vgl Lohse 1985:160163).

In sy soeke na God het Luther se Skrifverstaan gaandeweg vorm aangeneem, deur sy ontdekking dat daar nie 'n buite bepaaldheid is waarvolgens hy tot 'n duideliker verstaan van God sal kom nie. In hierdie worsteling en soeke het hy gepraat van die maskers van God (vgl Bornkamm 1965:55-74). Daar is iets van God sigbaar in die natuur, en tog kan die natuur God nie omvat nie, die natuur is eintlik net 'n masker van God wat God verberg, want God is bokant alles en groter as alles in die natuur. Daar is iets van God sigbaar in die geskiedenis, in die groot gebeure en in die groot figure, en tog kan die geskiedenis God nie omvat nie, die geskiedenis is 'n masker van God. Luther sê dan van God: "Hy Self handel deur ons, en ons is maar net sy masker waaragter Hy Homself verberg ..." (Bornkamm 1965:60). God is bokant almal en alle gebeure, en hy is groter as die geskiedenis. Die filosofie sê so baie ingrypende en wonderlike dinge in sy nimmereindigende besinning, maar ook daar is God uiteindelik die verborge God en is die 
filosofie 'n masker van God. God is 'n verborge God, 'n God na Wie geen pad vanuit ons filosofiese besinning ons lei (Bornkamm 1965:63). Uiteindelik sê Luther in 'n Lesing oor Galasiërs (in 1531) dat die wêreld nie in staat is om te onderskei tussen God en sy masker nie (Bornkamm 1965:68). Bornkamm vertolk dit so: "Geen konsep, geen beeld, geen metafoor uit ons fantasie is toereikend vir 'n onverdeelde en samehangende siening van God" (Bornkamm 1965:66). God verkies egter om Hom wel te openbaar aan die mens, en niemand kan aan God voorskrywe hoe om dit te doen nie. God openbaar Hom in Jesus Christus, en Luther beskrywe Christus met klem as God se Woord, want God kommunikeer deur woorde. Wanneer ons ons aandag op Jesus Christus vestig, en soek na sy voetspore in die Bybel, begin ons die Bybel beter verstaan. Wat duidelik word van Luther se verstaanshorison is dat daar buite Jesus Christus niks is, geen pad na God bestaan nie, en buite Christus is daar ook geen verstaan van die Bybel nie. Om die Bybel te verstaan, beteken daarom om na Christus in die Bybel te soek. Van God wat Hom openbaar in Jesus Christus, Hy wat in die eerste plek die Woord van God is (en die Bybel is dit alleen in afgeleide sin, in relasie tot Christus), sê Luther dan uiteindelik in 'n Lesing oor Genesis (1535-45): "As jy glo in die geopenbaarde God en sy Woord aanvaar, dan sal Hy ook geleidelik die verborge God aan jou openbaar" (Bornkamm 1965:73).

Onder die invloed van die filosofieë van Immanuel Kant en G W F Hegel kom daar in die 19de eeu dramatiese verskil in die hermeneutiese benadering van die historiese kritiek en die liberale teologie. (Friedrich Schleiermacher word as die vader van die Liberale Teologie beskou.) Die Bybel word nou benader met 'n verstaanshorison van buite die Bybel - vanuit die verstaanshorison van die eietydse filosofie (vgl Thiselton 2007:293).

Die 19de se strewe om die Bybel op objektief-wetenskaplike wyse te benader, lei na die histories-kritiese metode vir die interpretasie van die Bybel. Die historiese kritiek se verstaanshorison vanuit die eietydse filosofie was:

Eerstens het dit die 17de eeuse rasionalistiese aanname bly handhaaf, waarvolgens die gebruik van die menslike rede, vry van teologiese beperkinge, beskou was as die beste instrument om die Bybel te bestudeer. Dit het beteken dat hulle die Bybel op dieselfde wyse hanteer het as enige ander literatuur, en nie as God se besondere openbaring aan die mensdom nie. Tweedens het die Histories-Kritiese metode 'n naturalistiese wêreldverstaan vooronderstel, waarvolgens alles verklaar moes word volgens wette van die natuur, en alle geskiedenis was dan deel van 'n evolusionêre proses van ontwikkeling, en op hierdie wyse het hulle die moontlikheid van wonders en bonatuurlike ingryping uitgeskakel. Derdens het die Histories-Kritiese metode vroeër tye as "primitief" 


\section{Die Reformasie en Skrifinterpretasie}

en later periodes as "gevorderd" beskou, en daarby is Bybelse beskouings as tydsgebonde waarhede en nie as tydlose waarhede beskou nie, en dit het beteken dat die Bybel bloot vermeld het wat mense gedink het op 'n spesifieke tyd. Vierdens is aanvaar dat die Bybel se ware bydrae sy morele en etiese waardes was, en nie so seer sy teologiese leringe nie.

(Klein et al 1993:44; my parafrase)

Die verstaanshorison van buite, in die historiese kritiek, word duidelik in twee beslissende verskuiwings wat nou plaasgevind het in die fokus van die interpretasie van die Bybel:

Eerstens, eerder as om, soos in die verlede, te probeer uitmaak wat 'n teks gesê het, het baie geleerdes nou gepoog om, buite die Bybel, die bronne agter die teks te ontdek. Hierdie metode is die bronne-kritiek genoem. Tweedens, eerder as om die Bybel te aanvaar as die tydlose Openbaring van God, het baie geleerdes nou eerder gepoog om, buite die Bybel, die historiese ontwikkeling vas te stel wat vermoedelik onderliggend aan die teks was. In die benadering van historiese tekste, insluitende die Bybel, het hulle geredeneer dat die korrekte verstaan van 'n teks alleen bepaal moes word op basis van die historiese konteks, alleen op die basis van die spesifieke historiese toestande en omstandighede waaronder dit geskrywe is.

(Klein et al 1993:44; my parafrase)

Die historiese kritiek het daartoe bygedra dat sommige aanvaar het dat die Bybel se ware bydrae sy etiese waardes was. Omdat aanvaar is dat dit onmoontlik was om, in die lig van die Kantiaanse filosofie, objektief oor God te praat, en omdat die objektiewe denke oor God (binne die raamwerk van die natuurwetenskaplike benadering) baie gebring het by 'n religie van onsekerheid oor enigiets daar buite en daar bo, het die fokus verskuiwe na die ideale van die moraliteit. Met verwysing na Kant se beskouings van die praktiese rede, is daar oor God alleen subjektief gepraat, op basis van die moraliteit in die menslike bewussyn. Op hierdie wyse het die menslike bewussyn die enigste vertrekpunt vir etiese en religieuse denke geword (vgl Labuschagne 2007:7).

Teen die agtergrond van die Kantiaanse beskouing van die menslike bewussyn as die enigste vertrekpunt vir etiese en religieuse denke, het Schleiermacher vervolgens 'n verstaanshorison van 'n van buite bepaaldheid in sy interpretering van die Skrif. Reginald Moxon wys daarop dat in Schleiermacher se hermeneutiek daar nie in die Bybel self begin moet word 
om tot die verstaan van 'n gedeelte te kom nie, maar dat daar begin moet word by 'n ondersoek van daardie vermoë wat die boodskap ontsluit, naamlik die menslike gemoed en sy "Gods-bewusssyn" (Thiselton 2007:293).

Karl Barth keer die hele hermeneutiese proses van die 19de eeu om. Barth sê daar is met die subjektiewe vertrekpunt, soos by Schleiermacher, hermeneuties verkeerd begin. Daar is begin by die mens se soeke na kennis en die metodes om by kennis uit te kom. Eers daarna word beweeg na die saak wat ondersoek word: die realiteit. Die volgorde is daarmee dus: eers kennis (metode), daarna die realiteit. Uiteindelik bepaal die menslike metode die realiteit waarby uitgekom wil word. Barth sê die volgorde moet andersom wees. Daar moet begin word by die realiteit en daarna uitgekom word by die kennis daarvan. Hierdie hermeneutiek van Barth hou verband met sy vra na die realiteit van God: Hoe kan 'n mens praat oor God? Hoe kan 'n mens by God uitkom met jou menslike voorwaardes van filosofiese metodologie, histories-wetenskaplike ondersoek, met enigiets vanuit die mens? Uiteindelik loop Barth die pad van Luther: Daar is nie 'n pad van die mens na God nie; daar is alleen 'n pad van God na die mens. Die realiteit van God se pad na die mens is God se self-openbaring in Jesus Christus wat mens geword het (vgl Schwöbel 2005:17-35). In die dialektiese teologie, soos by Karl Barth en Emil Brunner, is waarheid uiteindelik dan alleen te verstaan in geloof se ontmoeting met die lewende God in Jesus Christus. In hierdie ontmoeting hoor die gelowige God se Woord vanuit die Bybel, wanneer die Heilige Gees die mensewoord van die Bybel tot God se Woord in die hart van gelowiges maak. Dit beteken uitdruklik dat alleen God beskik oor sy Woord.

Hans-Georg Gadamer kritiseer in sy dialektiese hermeneutiek daardie soort objektiewe historiese navorsing wat ervaring so verstaan dat dit geheel georiënteer is op kennis en metode (die metode om kennis te bereik), terwyl die innerlike historiese ingesteldheid van ervaring nie aan die orde kom nie. Dit beteken, in hierdie verkeerde siening, dat ervaring so verobjektiveer word dat geen historiese moment daaraan vasgryp nie, want inderwaarheid word in die wetenskaplike eksperiment met verobjektivering die objek uit sy historiese moment uitgehaal en herstruktureer om aan te pas by die wetenskaplike metode en om in te val by die hermeneutiese vooronderstellings van die navorser. Gadamer sien uitdruklik die histories-kritiese metode van die 19de eeu se teologie op hierdie verkeerde pad (Palmer 1977:194). Die historiese Jesus van hulle navorsing is daarmee dan eintlik alleen produk van hulle metode en hermeneutiese vooronderstellings.

Hierteenoor stel Gadamer sy versigtig uitgewerkte dialektiese hermeneutiek waarin die innerlike historiese ingesteldheid van ervaring aan 


\title{
Die Reformasie en Skrifinterpretasie
}

die orde kom. Hiervolgens word die waarheid nie metodologies bereik nie, maar dialekties. Palmer verduidelik Gadamer se siening so:

\begin{abstract}
Gadamer's approach, then, is closer to the dialectic of Socrates than to modern manipulative and technological thinking. Truth is not reached methodically but dialectically; the dialectical approach to truth is seen as the antithesis of method, indeed as a means of overcoming the tendency of method to prestructure the individual's way of seeing. Strictly speaking, method is incapable of revealing new truth; it only renders explicit the kind of truth already implicit in the method.
\end{abstract}

(Palmer 1977:165)

Wanneer hy dialekties praat van "ervaring" en die "fusie van horisonne" in die ontmoeting tussen menslike bewussyn (navorser) en die objek (teks wat nagevors word), is sy hermeneutiese vertrekpunt nie die mens (navorser) se subjektiwiteit (met sy metodes en vooropgestelde idees) nie, maar wat hy wel doen is om 'n posisie in te neem wat toelaat vir'n groter mate van dinamiese interaksie (tussen navorser en objek van navoersing). Hy sluit dan ook aan by die latere Heidegger wat hermeneutiese verstaan uitsluitlik in passiewe terme verduidelik: Verstaan word nie langer bloot subjektief as 'n daad van die mens beskou nie, maar dit word verstaan as 'n gebeure in die mens (Palmer 1977:216).

Gadamer se dialektiek is uitdruklik anders as die dialektiek van Hegel. Hegel se dialektiek is sterk subjektivisties, met self-bewussyn in die kern van Hegel se denke, en met die self-objektivering van die bewussyn in die dialektiese proses. Maar Gadamer se dialektiek is nie gegrond in selfbewussyn nie, maar wel in syn - wel in die linguistikaliteit wat deel uitmaak van die menslike syn in die wêreld, in die ontologiese karaktervan die linguistiese gebeure (Palmer 1977:165,166). Taal is vir hom draer van die ervaring van die verlede en die geskiedenis (Palmer 1977:213).

Gadamer se dialektiese hermeneutiek dui op 'n dialektiek (of dialektiese spanning) tussen die verstaanshorison van die navorser en die woorde of teks vanuit die geskiedenis of tradisie wat met die navorser in ontmoeting tree. Sy verstaan van ervaring is hiermee in die historiese navorsing nie bloot 'n relaas van die navorser se persepsies nie, maar om te ken vanuit 'n ontmoeting en 'n gebeure. In sy werk, "Wahrheit und Methode: Grundzüge einer philosophischen Hermeneutik" (1960) (Truth and method: Elements of a philosophical hermeneutics), verwys Gadamer na 'n soort kapasiteit vir verstaan deur ervaring, en sê dan dat ervaring sy verwesenliking het "not in a knowing but in an openness for experience, which is itself set in 
free play by experience" (Palmer 1977:166, 195). Ervaring is, in Gadamer se dialektiek, dan 'n produk van die ontmoeting tussen die menslike bewussyn (van die navorser) en die objek (wat nagevors word). Ervaring is daarom nie 'n gearriveerde benadering in objektiveerbare kennis nie, is nie 'n soort kennis in die sin van vaste inligting wat ten opsigte van hierdie of daardie objek of aangeleentheid bewaar word nie. Dit gaan nie om so 'n finale bloudruk nie. Ervaring is deel van die historiese natuur van die mens. Ervaring hou eerder verband met ' $n$ interpreterende ontmoeting, dit suggereer die pyn van groei en telkens opnuut tot verstaan kom (vgl Palmer 1977:195, 196). Hy sê in sy "Wahrheit und Methode": "Every experience runs counter to expectation if it really deserves the name experience" (Palmer 1977:196). In die mens se natuur van historiese eksistensie is daar inderdaad 'n element van negatiwiteit wat openbaar word in ervaring. Maar, sê Gadamer: "The fact that 'experience' is preeminently painful and unpleasant does not really colour experience black; it lets us see into the inner nature of experience" (Palmer 1977:196).

Thiselton wys daarop dat Calvyn 'n belangrike tema van ons tyd antisipeer het in sy Institusie: "Calvin anticipates a major theme in modern theology with his emphasis upon humankind's distinctive capacity to be addressed by the word of God in communicative and revelatory action" (Thiselton 2007:211).

Calvyn sê in sy Institusie (Boek Een, hoofstuk V, 9) van hierdie kapasiteit van die mens, om deur God in 'n kommunikatiewe aksie aangespreek te word, dit wil sê 'n kommunikatiewe aksie wat van buite die mens die mens toetree:

\begin{abstract}
Hence it is obvious that, in seeking God, the most direct path and the fittest method is, not to attempt with presumptuous curiosity to pry into his essence, which is rather to be adored than minutely discussed, but to contemplate him in his works, by which he draws near, becomes familiar, and in a manner communicates himself to us. we need not go far in search of him (Acts 17:27), because, by the continual working of his power he dwells in every one of us.
\end{abstract}

(Calvin 1964:57, 58)

Calvyn praat van 'n "tweevoudige kennis" van God in beide die skepping en die "algemene leerstellings van die Skrif" (Boek Een, hoofstuk II, 1), maar wanneer hy uitbrei oor die openbaring van God in die Skrif, of "onder die Evangelie", dan onderskei hy met 'n "nou ten volle geopenbaar aan ons" (Boek Twee, hoofstuk IX, 1) - (Calvin 1964:40, 363). Hoewel Calvyn in die algemeen verwys na die openbaring van God in die Skrif, kwalifiseer hy in sy uiteensetting tog die openbaring as in Christus, en verwys byvoorbeeld na 


\section{Die Reformasie en Skrifinterpretasie}

"kennis en lig wat manifesteer word in die Persoon van Christus" (Boek Twee, hoofstuk IX, 1) - in aansluiting by Skrifgedeeltes soos Matteus 13:16, Lukas 10:23, Johannes 1:18, Hebreërs 1:1 \& 2 en II Kor 4:6 (Calvin 1964 364). Daarmee is Calvyn nader aan Luther, wat Christus met klem as God se Woord beskrywe.

Hierdie tema, van 'n kommunikatiewe aksie wat van buite die mens die mens toetree, vind ons onder andere in diepte ondersoek by Gadamer, wanneer Gadamer praat van 'n hoër soort objektiwiteit, waar ons gelei word deur dinge eerder as deur ons eie subjektiwiteit (vgl Palmer 1977:212-217). Palmer sê: "Gadamer's hermeneutics suggests a new kind of objectivity (Sachlichkeit) grounded in the fact that what is disclosed constitutes not a projection of subjectivity but something which acts on our understanding in presenting itself" (Palmer 1977:212).

Hiermee konfronteer Gadamer ons met die moontlikheid om weg te beweeg van 'n siening van ervaring as 'n aktiwiteit van die subjek (navorser) na 'n siening van ervaring as 'n aktiwiteit van die objek (of situasie) wat in beweging kom en die subjek (navorser/leser) aangryp. Gadamer praat van "om gelei te word deur dinge eerder as deur subjektiwiteit" en: "... the meaning of an event or the sense of a text - was no firm and self-enclosed object for us merely to identify and describe. For the historical consciousness includes in itself actually a mediation of past and present" (Palmer 1977:213).

Gadamer waarsku teen 'n benadering van die geskiedenis waarin in die aanspraak op objektiwiteit, die een wat vra na kennis sy hand oorspeel en inderdaad eintlik aanspraak daarop maak om meester oor die boodskap van die verlede te wees (Palmer 1977:193). Gadamer sien dit as 'n refleksiewe projeksie van die ondersoeker se oortuigings om bepalend in te werk op die woorde en aksies van die persoon in die verlede, 'n soort kennisname waarin die hede reeds gedogmatiseer is om buitekant die invloedsfeer van die teks te staan. Palmer verduidelik hierdie misbruik van verstaan so: "But it is just this subtle kind of mastery through understanding which uses understanding merely to see history 'out there' as a reflexively constituted thou; it objectifies it and effectively destroys its real claim to meaningfulness" (Palmer 1977:193).

Stephen Strasser sê van hierdie "reflexively constituted thou", dat dit van die navorser, in die "I-thou relationship" van die navorsing, sou veronderstel dat "he understands the other better than the other himself does" (Palmer 1977:192). Hierteenoor stel Gadamer sy beter hermeneutiese benadering van, wat hy noem, die "wirkungsgeschichtliche Bewusstsein" ("n bewussyn waarin die geskiedenis aan die werk is"), of wat Theodore Kisiel vertaal as "historically operative consciousness" - (Palmer 1977:191 Die wirkungsgeschtliche Bewusstsein dui basies vir Gadamer op 'n ek-jy 
verhouding wat gekarakteriseer word deur 'n outentieke openheid vir die ander. Dis 'n soort openheid wat die wil het om die ander aan te hoor, die wil het om gemodifiseer te word deur die ander, eerder as om reflekterend meester te probeer wees en jou eie stempel af te druk. Palmer sê:

"Authentically historical consciousness ... does not see the present as the apex of truth; it holds itself open for the claim which the truth in the work can address to it" (Palmer 1977:193). Dit wil sê 'n "wirkungsgeschichtliche Bewusstsein" ('n bewussyn waarin die geskiedenis aan die werk is") dui op 'n nie-objektiveerbare ervaring wat die navorser voorberei het, wat hom ontvanklik en oop gemaak het vir die verlede, die geskiedenis en die tradisie, en dit dui beslis nie op 'n bewussyn wat klaar vooropgestelde idees en eietydse sisteme het waarby alles moet inpas nie, wat klaar besluit het hoe die geskiedenis moet lyk nie (vgl Palmer 1977:191-193).

Die filosofiese invloed van Gadamer is baie sterk in die "nuwe hermeneutiek" van Gerhard Ebeling en Ernst Fuchs, met hulle siening van "woord-gebeure" waarin 'n eie unieke waarheid gekommunikeer word (vgl Labuschagne 2007:35, 36).

Die uitdaging bly om iets te probeer maak van 'n moontlike balans en in sinvolle uitweg tussen die hermeneutiese benaderings van van binne bepaaldheid en van buite bepaaldheid - sodat waarheid en werklikheid in die boodskap van die Skrif nie skade aangedoen word nie.

\section{SAMEVATTING}

In die hedendaagse debat is die postmoderne invloed baie krities ingestel teen gearriveerde denke in wat beskou word as fundamentalisme (in 'n identiteit wat gestel word tussen Woord van God en woord van die mens in die Bybel) en, nou-verwant daaraan, fondamentalisme (in die afdwing van onbuigsame sisteme en finale beginsels). In die gees van 'n postfondamentalistiese ingesteldheid word, daarteenoor, meer positief gereageer op openheid, pluraliteit en die besondere van die partikuliere. In hierdie debat het die Reformasie inderdaad opnuut weer relevant geword, en word daar opnuut weer na die reformatore geluister. En die rede daarvoor is daarin geleë dat die Reformatore, en spesifiek dan Luther en Calvyn, met hulle nuwe hermeneutiek van die Skrif die gearriveerde denke van die Middeleeuse kerk weer oopgebuig het vir 'n kritiese ingesteldheid ten opsigte van bron en teks en vir nuwe verstaansmoontlikhede. Sola Scriptura het in die Reformasie-proses alles verander.

Dit is 'n onlogiese argument om sonder meer te verwys na nuwe Protestantse hermeneutiese benaderings as benaderings wat ' $n$ breuk sou verteenwoordig met die Reformasie en die Reformasie se hermeneutiek, want 


\section{Die Reformasie en Skrifinterpretasie}

die Reformasie se hermeneutiese benadering is met sola Scriptura'n oop benadering wat juis daartoe aanleiding gee dat altyd weer opnuut gedink moet word vanuit die Skrif, en dat daar gevolglik nuwe benaderings kàn volg. Wel kan daarop gewys word dat die Reformasie tog ook ander vooronderstellings het in sy hermeneutiek as die vooronderstellings van sommige teoloë en verskeie teologiese strominge van ons tyd.

Wat duidelik geword het in hierdie studie is dat in die eietydse hermeneutiese debat die Reformasie altyd ' $n$ waardevolle bydrae sal lewer, nie alleen om die aanleidende faktore van vandag se hermeneutiese denke aan te toon nie, maar om spesifiek ook die waarde van 'n van binne bepaalde verstaanshorison te stel teenoor dié van 'n van buite bepaaldheid. En juis só, met hierdie verstaanshorison, dwing die Reformasie ons om weer na sy stem te luister en oorweging te gee aan sy argumente, sekerlik binne die debatte van ook ander stemme van 'n van binne bepaalde verstaanshorison en ander stemme van 'n van buite bepaalde verstaanshorison. Laat ons tegelyk daarteen waak om nie besig te wees om óf enersyds so vas te hou aan onhoudbare en onbuigsame voorkeure uit die verlede óf andersyds die Skrif so aanvaarbaar vir ons tyd en die kontemporêre debat te probeer verklaar dat ons dalk, in albei gevalle, nie meer die boodskap van die Skrif hoor nie. Die uitdaging bly om telkens met grondige denke na te dink en tot verantwoordbare en verantwoordelike konklusies te kom - sodat ons so naby as moontlik mag kom aan die waarheid van die Evangelie van Jesus Christus.

Dit bly tot voordeel van die debat, in die soeke na groter insig, om op die hoogte te kom van die ontwikkeling van denkstrominge deur die eeue, tot by die punt waar ons vandag is.

David Tracy (in Thiselton 2007:112) sê wel tereg: “... there is no one central interpretation around which all interpretations focus." Daarom sal ons nooit klaar gepraat kom oor die interpretasie van die Bybel nie. Die soeke van die hermeneutiek sal aangaan. Die stemme uit die verlede sal altyd daar wees om 'n waardevolle bydrae te lewer, en ons te leer om weer ook na hulle te luister, met die openheid dan wat die Reformasie ons geleer het. Die kerk van die Reformasie hou immers nooit op om te hervorm nie! Dit bly 'n oop strewe om hermeneyties so naby as moontlik aan die waarheid te kom!

\section{Literatuurverwysings}

Bainton, R H 1950. Here I stand - A life of Martin Luther. New York: The New American Library.

Bornkamm, H 1965. Luther's world of thought, translated en edited by M H Bertram. St Louis, MO: Concordia. 
Calvin, J 1947. Commentaries on the epistle of Paul the apostle to the Romans, translated and edited by J Owen. Grand Rapids, MI: Eerdmans

Calvin, J 1949. Commentary on The Book of Psalms, translated from the original Latin, and collated with the author's French version by J Anderson. Grand Rapids, MI: Eerdmans.

Calvin, J 1963. Calvin's Commentaries - Hebrews and I \& II Peter, translated by W B Johnston and edited by D W Torrance \& T F Torrance. Grand Rapids, MI: Eerdmans.

Calvin, J 1964. Institutes of the Christian religion, tr by H Beveridge. Grand Rapids, $\mathrm{Ml}$ : Eerdmans.

Douglas, J D (ed) 1974. The New International Dictionary of the Christian Church. Exeter: Paternoster.

Forell, G W (ed) \& Lehmann, H T (gen ed) 1970. Luther's works, Vol 32. Philadelphia, PA: Fortress.

Grimm, H J (ed) \& Lehmann, HT (gen ed) 1971. Luther's works, Vol 31. Philadelphia, PA: Fortress.

Hagen, K 1998. Martin Luther (1483-1546), in McKim 1998:212-220.

Klein, W W et al 1993. Introduction to Biblical interpretation. Dallas, TX: Word.

Labuschagne, J P 2007. The controversy of the 19th and 20th Century theology. Lesings: Module CHS 154/CHI 144, 1-50. Pretoria: Fakulteit Teologie, Universiteit van Pretoria.

Lehmann, H T (gen ed) \& Doberstein, J W (ed) 1973. Luther's Works, Vol 51. Philadelphia, PA: Fortress.

Linder, R D 1974. The Reformation, in Douglas 1974:830-831.

Lohse, B 1985. A short history of Christian doctrine, tr by F E Stoeffler. Philadelphia, PA: Fortress.

Luther, M 1970. Luther at the diet of worms (1521), tr by Roger A Hornsby, in Forell \& Lehmann 1970:103-115.

Luther, M 1971. Heidelberg disputation (1518), tr by H J Grimm, in Grimm, \& Lehmann 1971:37-70.

Luther, M 1972. Lectures on Romans: Scholia (Chapters 1-2), tr by W G Tillmanns, in Oswald 1972:133-193.

Luther, M 1973a. The Last Sermon, Eisleben 1546, tr by John W Doberstein, in Lehmann \& Doberstein 1973:381-392.

Luther, M 1973b. Commentary on 1 Corinthians 7, 1 Corinthians 15 and lectures on 1 Timothy, tr by Martin H Bertram, in Oswald 1973:57-213.

Luther, M 1974. First lectures on the Psalms I (Psalms 1-75), tr by $\mathrm{H} \mathrm{J}$ A Bouman, in Oswald 1974:1-484.

McKim, D K (ed) 1998. Historical handbook of major Biblical interpreters. Leicester: InterVarsity.

Muller, R A 1998. Biblical interpretation in the 16th \& 17th centuries, in McKim 1998:123-152.

Oswald, H C (ed) 1972a. Luther's works, Vol 25. St Louis, MO: Concordia.

Oswald, H C (ed) 1973c. Luther's works, Vol 8. St Louis, MO: Concordia.

Oswald, H C (ed) 1974b. Luther's works, Vol 10. St Louis, MO: Concordia.

Palmer, R E 1977. Hermeneutics. Evanston, IL: Northwestern University Press.

Puckett, D L 1998. John Calvin (1509-1564), in McKim 1998:171-179.

Rupp, E G \& Drewery, B (eds) 1970. Martin Luther. London: Edward Arnold. 


\section{Die Reformasie en Skrifinterpretasie}

Schwöbel, C 2005. Theology (of Karl Barth), in Webster 2005:17-36.

Thiselton, A C 2007. The hermeneutics of doctrine. Grand Rapids, MI: Eerdmans.

Webster, J 2005 (ed). The Cambridge Companion to Karl Barth. Cambridge:

Cambridge University Press. 